\title{
TAMBEROS DE LA CUENCA LECHERA CENTRAL SANTAFESINA. ¿PRODUCTOR ASOCIADO O MANO DE OBRA?
}

\author{
Sandoval, P. S. M. ${ }^{1}$; Leonardi, R. ${ }^{1} ;$ Pernuzzi, C. ${ }^{1} ;$ Alanda, G. ${ }^{2}$; \\ Benitez, R..$^{1} ;$ Arnaudo, J. P. ${ }^{1} ;$ Brance Bonvini, M. I. ${ }^{1 .}$ \\ Acosta, G. ${ }^{2} ;$ Eggel, A. ${ }^{3} \&$ Martins, L. ${ }^{4}$
}

\begin{abstract}
RESUMEN
El proceso de modernización del agro de las dos últimas décadas, incide directamente en un sujeto social de la cuenca lechera santafesina. 1990 genera nueva legislación que enmarca el trabajo y la vida del tambero y su familia, reconfigurando este sujeto social fundamental. La metodología cualitativa utilizada fue Estudio de Caso sobre el Departamento las Colonias. Los resultados presentados en este artículo demuestran que los cambios ocurridos por la nueva figura legal del tambero, impactan en sus condiciones de vida. A pesar que la nueva legislación convierte al empleado tambero en productor asociado, no provoca mejoras en su situación socioeconómica. El trabajo completo es un proceso de articulación entre actividad científica y desarrollo rural, donde se identificaron y sistematizaron los contextos de ambas situaciones legales y los cambios en las condiciones de vida del tambero y su familia, suministrando conocimientos para orientar la tarea de extensión relacionada al desarrollo rural.
\end{abstract}

Palabras clave: Cambios sector agropecuario, Ley del tambero asociado, Ley del tambero mediero, Reconfiguración sujeto social.

\footnotetext{
1.- Facultad de Ciencias Agrarias, Universidad Nacional del Litoral. Kreder 2805 (3080) Esperanza, provincia de Santa Fe. Telefax 03496-426400. Email: psandoval@fca.unl.edu.ar

2.- Ministerio de la Producción. Boulevard Pellegrini 3100. (3000) Santa Fe. Tel: 543424505300 -

3.- Facultad de Humanidades y Ciencias (UNL). Ciudad Universitaria. (3000) Santa Fe.

4.- Instituto Nacional de Tecnología Agropecuaria (INTA). AER Galvez. Lisandro de la Torre y Belgrano.

(2252) Galvez, provincia de Santa Fe. Tel.: 03404-481 238.

Manuscrito recibido el 17 de mayo de 2017 y aceptado para su publicación el 15 de agosto de 2017.
} 


\begin{abstract}
Dairy farmers at dairy basins in Santa Fe: production associates or labour force members?

In the last two decades, modernization process of the agricultural sector, has a direct impact in the social subject of Santa Fe dairy basin. 1990 generates new legislation that frames the work and life of the tambero and his family, reconfiguring this fundamental social subject.

The qualitative methodology used was case study on the Department of the Colonies. The results presented in this article show that changes by the new legal figure of the tambero, have an impact on their living conditions. Despite the fact that the new legislation makes - from the letter - dairy employee in associate producer, it does not cause improvements in their social status.

The complete study is an articulation process between research and rural development, were identified and systematized the context of both legal situations; and changes in the conditions of life of the tambero and his family, providing expertise to guide the task of extension related to rural development.
\end{abstract}

Key words: Agriculture changes, Associated tambero law, Mediero dairy law, Social subject reconfiguration.

\section{INTRODUCCIÓN}

El proceso de crecimiento y desarrollo tecnológico del agro no tuvo un transcurso equivalente con la mejora en las condiciones de vida de las familias rurales (21 y 23); y específicamente con la familia del empleado tambero de la cuenca lechera central santafesina. En el período 1988-2008, un lapso de 20 años relevados por tres censos agropecuarios, se perdieron en el departamento las Colonias 1.334 EAPs de las cuales el 70\% eran eaps lecheras (926 tambos). (INDEC 1988-2002 y 2008). En suma, se perdió un $50 \%$ de los tambos totales en tan solo 20 años y con ellos, se expulsaron del sector a más de 900 familias tamberas.

Por otro lado, los empleados tamberos que quedaron, son identificados por los demás actores sociales ("productores” y "profesionales" del sector agropecuario) como una limitante a la eficiencia de los establecimientos lecheros. Eficiencia basada en la falta de adopción de tecnología para el aumento de los rendimientos y el mejo- ramiento en la calidad del producto, ambos destinados al crecimiento económico del sistema productivo. (1,2 y 3$)$

Actualmente, los empleados a cargo de las tareas de establecimientos lecheros han mutado su situación legal a partir de la aparición de la ley del tambero asociado, con las consecuentes modificaciones de su anterior estilo de vida.

Sin embargo, no hay estudios que den cuenta de los cambios ocurridos entre estas dos legislaciones que regulan las condiciones de trabajo y de vida de la familia tambera. Razón que fundamentó la realización de la presente investigación.

\section{OBJETIVOS}

\section{General:}

Resignificar al sujeto social trabajador tambero en el contexto de la nueva ruralidad.

Revista FAVE - Ciencias Agrarias 16 (2) 2017 